\title{
Tingkat Kepercayaan Masyarakat terhadap Kulawu Tello dalam Mengatasi Kerabang Telur Lunak di Kabupaten Sidenreng Rappang
}

\author{
The level of public trust in Kulawu Tello precious stone to Overcoming Soft Shelled Egg \\ in Sidenreng Rappang Regency
}

\author{
A. Salam ${ }^{1}$, R.H.M. Cosmas ${ }^{1}$, N. Munir $^{2}$, W.F. Sari ${ }^{3}$, T. Mulawansyah ${ }^{4}$, dan M.F. Latief. ${ }^{5}$ \\ ${ }^{1}$ Fakultas Peternakan, Universitas Hasanuddin \\ Jl. Perintis Kemerdekaan KM. 10, Tamalanrea, Makassar 90245 \\ Corresponding e-mail: daengfadhli@gmail.com +6282293110406
}

\begin{abstract}
Kulawu Tello is a stone that is believed by the community that come from inside the egg, usually this stone is used in the breeding of laying hens (layers) by breeders, especially in overcoming the problem of soft shelled egg. In this study aims to determine the effect of Kulawu Tello on the local community. The sample in this study was 78 people consisting of layer farmers who use and know about Kulawu Tello, local historians and the village head of Manisa Village. This research is descriptive, using a questionnaire to determine the level of trust of the Sidenreng Rappang community on the magical ability of Kulawu Tello in improving the performance of layers. The level of trust of each individual varies depending on how they believe in something according to what has been done. In general, people have high level of trust in the efficacy of Kulawu Tello stone because it has been used in their livestock business. It can be concluded that the level of public trust in Kulawu Tello in overcoming soft egg shells is very high, namely $52.56 \%$, the percentage of moderate trust level is $21.38 \%$ and those who have a low level of trust are $5.13 \%$. As for the level of public trust in Kulawu Tello in order to improving the performance of layers around $47.44 \%$, the percentage of medium trust level around $26.49 \%$ and those who have a low level of trust around $4.27 \%$.
\end{abstract}

Keywords: belief, kulawu tello, magic, soft shelled egg.

\begin{abstract}
ABSTRAK
Kulawu Tello merupakan batu yang dipercaya oleh masyarakat berasal dari dalam telur, biasanya batu ini digunakan dalam pemeliharaan ayam petelur (layer) oleh peternak khususnya dalam mengatasi masalah kerabang telur yang lunak. Penelitian ini bertujuan untuk mengetahui tingkat kepercayaan Masyarakat Sidenreng Rappang terhadap kemampuan magis Kulawu Tello dalam meningkatan performa ayam petelur. Responden pada penelitian ini sebanyak 78 orang yang terdiri dari peternak ayam yang menggunakan dan yang mengetahui Kulawu Tello, sejarawan setempat dan lurah Kelurahan Manisa. Penelitian ini bersifat deskriptif, menggunakan kuesioner dan wawancara. Tingkat kepercayaan tiap individu berbeda-beda tergantung bagaimana mereka meyakini sesuatu sesuai dengan apa yang telah dilakukannya. Pada umumnya masyarakat memiliki kepercayaan yang tinggi terhadap khasiat dari batu Kulawu Tello karena telah menggunakan pada usaha peternakannya. Kepercayaan masyarakat terhadap Kulawu Tello dalam mengatasi kerabang telur yang lunak sangat tinggi yaitu sebesar $52,56 \%$ adapun persentase tingkat kepercayaan sedang $21,38 \%$ dan yang memiliki tingkat kepercayaan kurang yaitu $5,13 \%$, adapun untuk tingkat kepercayaan masyarakat terhadap Kulawu Tello dalam meningkatkan performa ayam petelur sebesar $47,44 \%$ adapun persentase tingkat kepercayaan sedang $26,49 \%$ dan yang memiliki tingkat kepercayaan kurang yaitu 4,27\%.
\end{abstract}

Kata Kunci: kerabang telur lunak, kepercayaan, kulawu tello, dan magis.

\section{PENDAHULUAN}

Kehidupan masyarakat di Sulawesi Selatan khususnya Kabupaten Sindenreng Rappang saat ini masih menyisakan kearifan kebudayaan masa lalu. Peternak lokal mempercayai kekuatan magis dalam sebuah batu yang dapat mengatasi kerabang telur lunak pada ayam ras petelur. 
Peternak ayam ras petelur di Sidenreng Rappang mengahadapi berbagai tantangan dan hambatan mulai dari pakan, manajemen pemeliharaan, produksi telur dan lain- lainnya. Salah satunya yaitu permasalahan soft shelled egg atau kerabang telur lunak yang disebabkan karena kurangnya kandungan mineral pada pakan yang di konsumsi ayam ras petelur saat periode pertumbuhan dan periode bertelur.

Kepercayaan dinamisme dapat dilihat dari kepercayaan orang-orang Sidenreng Rappang terhadap batu mestika peninggalan nenek moyang seperti Kulawu Tello yang dianggap keramat, tuah dan berkhasiat untuk pengobatan. Kulawu Tello berasal dari bahasa bugis yang artinya kuning telur. Masyarakat sekitar menganggap Kulawu Tello sebagai batu mestika yang berasal dari dalam telur, terbagi dari beberapa warna yaitu putih bersih, putih kekuning-kuningan dan abu-abu. Seiring berjalannya waktu Kulawu Tello sudah semakin dikenali masyarakat di Kabupaten Sidenreng Rappang. Hal itu dikarenakan Kulawu Tello di percaya memiliki khasiat dalam mengatasi kerabang telur lunak dan meningkatkan produktivitas ayam petelur.

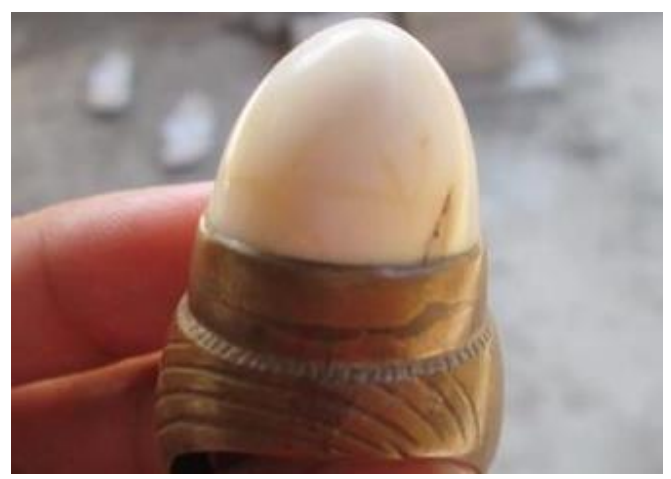

Gambar 1. Kulawu Tello

Kulawu Tello biasanya digunakan dalam pemeliharaan ayam ras petelur (layer) oleh peternak di Kabupaten terkhusunya peternak Desa Manisa Kecamatan Baranti dan Desa Mario Kecamatan Kulo. Penggunaan Kulawu Tello telah hadir jauh sebelum adanya industri peternakan ayam ras petelur di Kabupaten Sidenreng Rappang. Cara penggunaan Kulawu Tello yaitu dengan merendamnya di dalam tempat minum ternak selama \pm 12 Jam. Cara ini berasal dari ajaran nenek moyang terdahulu yang menceritakan pengunaan Kulawu Tello sebagai media pengobatan tradsional pada ayam kampung (Gallus gallus domesticus) untuk mengatasi kerabang telur lunak pada ayam, dan masih digunakan hingga saat ini.

Meningkatnya jumlah kasus kerabang telur lunak pada ayam ras petelur serta penggunaan mineral feed supplement yang dianggap mahal. sehingga peternak lebih memilih pengobatan tradisional menggunakan Kulawu Tello dalam mengatasi kerabang telur lunak. Dewi et al., (2019) menyatakan bahwa masyarakat memilih pengobatan secara tradisional disebabkan oleh adanya fakor kebudayaan dan pendidikan.

Berdasarkan Badan Pusat Statistik (2018) tercatat total populasi ayam ras petelur di Kecamatan Kulo sebanyak 990.600 ekor dan Kecamatan Baranti 399.400 ekor yang merupakan salah satu kecamatan dengan peternak ayam ras petelur terbanyak di Kabupaten Sidenreng 
Rappang. Belum adanya penelitian mengenai Kulawu Tello memunculkan ketertarikan bagi peneliti untuk mengetahui tingkat kepercayaan masyarakat terhadap Kulawu Tello dalam mengatasi kerabang telur lunak di kabupaten sidenreng rappang.

\section{METODELOGI}

Penelitian ini bersifat deskriptif, menggunakan kuesioner untuk mengetahui tingkat kepercayaan Masyarakat Sidenreng Rappang terhadap kemampuan magis Kulawu Tello dalam meningkatan performa ayam petelur di Kelurahan Manisa Kecamatan Baranti dan kecamatan Kulo, sampel yang menjadi informan pada penelitian ini sebanyak 78 orang yang terdiri dari peternak ayam yang menggunakan Kulawu Tello, sejarawan setempat dan lurah Kelurahan Manisa.

Kuesioner pada penelitian ini disusun merujuk pada studi yang dilakukan oleh Dewi dkk. (2019) yaitu pertanyaan mengenai persepsi masyarakat terhadap obat tradisional yang kemudian disusun kembali dengan memasukkan pertanyaan-pertanyaan untuk mengetahui tingkat kepercayaan masyarakat terhadap Kulawu Tello yang dipercaya mampu mengatasi kerabang telur yang lunak. Dilanjutkan dengan uji validitas dan reliabilitas agar didapatkan pernyataan yang valid pada lembar kuesioner.

Analisis data dari lembar kuesioner mengenai persepsi masyarakat terhadap Kulawu Tello dengan melakukan pemberian skor likert pada masing-masing pernyataan. Adapun kategori penilaian tertera pada Table 1.

Tabel 1. Kategori Penelitian Skor Likert.

\begin{tabular}{cc}
\hline Kategori & Skor \\
\hline Tinggi & 3 \\
Sedang & 2 \\
Kurang & 1 \\
\hline
\end{tabular}

Setiap pernyataan dan kategori yang telah diberikan nilai maka masing-masingnya akan dijumlahkan dan dikalikan dengan scale rating dari skor likert, dengan rumus sebagai berikut:

\section{Total $=\mathbf{T} \times \mathbf{P n}$}

Keterangan:

$\mathrm{T}$ : Total Jumlah responden yang memilih

Pn : Pilihan angka skor likert

Semua hasil yang didapatkan pada setiap kategori akan dijumlahkan disetiap pernyataan dan digunakan untuk menghitung persentase menggunakan rumus sebagai berikut:

$$
\text { Rumus indeks } \%=\frac{\text { Total Skor } \times 100}{Y}
$$

Keterangan:

Total skor : Total tiap kategori yang dijumlahkan untuk setiap pernyataan

Y : Skor tertinggi likert $\times$ jumlah responden 
Uji validitas ini dilakukan untuk memastikan bahwa masing-masing pertanyaan akan terklasifikasi pada variabel yang telah ditentukan. Validitas adalah tingkat keandalan dan kesalahan alat ukur yang digunakan. Instrumen dikatakan valid berarti menunjukkan alat ukur yang dipergunakan untuk mendapatkan data itu valid atau dapat digunakan untuk mengukur apa yang seharusnya diukur.

Uji reliabilitas pada suatu instrumen penelitian adalah sebuah uji yang digunakan untuk mengetahui apakah suatu kuesioner yang digunakan dalam pengumpulan data penelitian sudah dapat dikatakan reliabel atau tidak. Pada uji reliabilitas penelitian ini dilakukan dengan menggunakan analisis Alpha Cronbach. Dimana apabila suatu variabel menunjukkan nilai alpha $>0,60$ maka dapat disimpulkan bahwa variabel tersebut dapat dikatakan reliabel atau konsisten dalam mengukur (Dewi dan Sudaryanto, 2020).

\section{HASIL PENELITIAN}

Dari penelitian yang telah dilakukan dengan 78 responden yang mengetahui atau pernah menggunakan Kulawu Tello didapatkan hasil:

Tabel 2. Data Sosiodemografi Responden Kelurahan Manisa Kecamatan Baranti

\begin{tabular}{llc}
\hline Kategori & \multicolumn{1}{c}{ Keterangan } & Persentase (\%) \\
\hline \multirow{2}{*}{ Jenis Kelamin } & Laki-laki & 57,69 \\
& Perempuan & 42,31 \\
& $17-25$ & 34,61 \\
Umur & $26-35$ & 10,26 \\
& $36-45$ & 15,38 \\
& $46-55$ & 17,95 \\
& $56-65$ & 17,95 \\
Tingkat Pendidikan & 65-atas & 3,85 \\
& Tidak sekolah & 2,56 \\
& SD/Sederajat & 24,36 \\
& SMP/Sederajat & 14,11 \\
& SMA/Sederajat & 33,33 \\
& Perguruan tinggi & 25,64 \\
& Petani & 11,54 \\
& Peternak & 44,87 \\
& PNS/ASN & 2,56 \\
& Pelajar/Mahasiswa & 28,21 \\
& Pegawai swasta/BUMN & 0 \\
& Wiraswasta/Pedagang & 5 \\
& TNI/Polri & 0 \\
& Tidak bekerja & 5 \\
& 0 - 1.000.000 & 47,44 \\
& 1.000.000 - 3.000.000 & 23,08 \\
& 3.000.000 - 5.000.000 & 19,23 \\
& 5.000.000 - 7.000.000 & 7,69 \\
& Jumlah & 2,56 \\
\hline & & $\mathbf{1 0 0}$ \\
\hline & &
\end{tabular}


Berdasarkan Tabel 2. dapat dilihat bahwa sebagian besar responden berjenis kelamin laklaki yaitu sebesar 57,69\% sedangkan untuk perempuan yaitu 42,31\%. Hal ini dikarenakan responden laki-laki lebih banyak mengetahui tentang khasiat dan cerita dibalik batu Kulawu Tello. Selain itu laki-laki juga lebih tertarik dengan benda yang dipercaya memiliki kekuatan magis dibandingkan perempuan. Tentunya hal ini disebabkan adanya perbedaan psikologis dimana laki-laki memiliki sifat yang lebih aktif, agresif dan rasional dalam segala hal dibandingkan dengan perempuan (Suhardin, 2016).

Berdasarkan tingkat umur sebagian besar responden berada pada rentang umur 17-25 tahun yaitu sebesar $34,61 \%$ yang termasuk dalam kategori remaja akhir, diikuti oleh rentang umur 40-55 dan 56-65 sebesar 17,95\%, kemudian rentang umur 36-45 sebesar 15,38\%, kemudian rentang umur 26-35 sebesar 10,26\% dan yang terakhir yaitu umur 65-atas sebesar $3,85 \%$. Umur merupakan salah satu faktor yang mempengaruhi pengetahuan seseorang, seiring bertambahnya umur seseorang maka akan terjadi perkembangan baik perkembangan fisik maupun ilmu pengetahuannya. Selanjutnya pada rentang umur 46-55 dan 56-55 atau bisa dikatakan masa lansia (Amin dan Juniati, 2017). Pada umumnya rentang umur ini didominasi oleh masyarakat yang telah lama menggeluti dunia peternakan khususnya ayam petelur, sehingga mereka telah memiliki pengalaman yang banyak. Pengalaman adalah suatu kejadian yang pernah dialami seseorang dalam berinteraksi dengan lingkungannya, makin lama masa kerja maka pengetahuan akan semakin bertambah (Dharmawati dan Wirata, 2016). Selanjutnya pada rentang umur 36-45 tahun atau bisa dikatakan masa dewasa akhir (Amin dan Juniati, 2017). Pada rentang usia ini didominasi oleh kalangan masyarakat yang baru memulai usaha peternakan begitu pula pada rentang umur 26-35. Adapun pada umur 65-atas merupakan masa manula, dimana responden pada usia ini merupakan sesepuh dari daerah tersebut yang mengetahui banyak hal mengenai batu Kulawu Tello.

Berdasarkan tingkat Pendidikan, dapat dilihat bahwa sebagian besar responden memiliki tingkat pendidikan yaitu SMA/sederajat, perguruan tinggi, SD dan tidak sekolah. Hal ini tentunya dipengaruhi oleh banyak hal seperti kondisi perekonomian keluarga, biasanya perekonomian keluarga yang menengah ke bawah tidak melanjutkan pendidikan ke jenjang yang lebih tinggi. Namun, banyak juga kalangan peternak yang tidak menuntut ilmu di perguruan tinggi kemudian membuka usaha peternakan ayam petelur, mereka hanya mendapatkan pengetahuan berdasarkan pengalaman dan juga cerita dari sesama peternak. Dari sini kita dapat melihat bahwa pendidikan dapat mempengaruhi pengetahuan dari seseorang yaitu semakin tinggi pendidikan maka semakin tinggi pengetahuan seseorang karena pendidikan yang tinggi mempermudah menerima informasi baru (Corneles dan Losu, 2015).

Berdasarkan tingkat pekerjaan, dapat dilihat bahwa sebagian besar responden memiliki pekerjaan sebagai peternak, pelajar/mahasiswa, petani, PNS/ASN dan tidak bekerja. Pekerjaan 
ini dapat dipengaruhi oleh kondisi geografis dari suatu wilayah, tingkat pendidikan dan kondisi ekonomi. Seperti halnya di Kabupaten Sidenreng Rappang yang memang terkenal sebagai sentra peternakan ayam ras petelur terbesar di Provinsi Sulawesi Selatan (Rohani dkk., 2018). Kondisi geografis dari wilayah Kabupaten Sidenreng Rappang dan cuaca yang tidak ekstrim membuatnya sangat cocok dijadikan sebagai tempat pengembanagn usaha peternakan ayam petelur.

Berdasarkan tingkat pendapatan, dapat dilihat bahwa sebagian besar responden berada pada rentang 0-1.000.00 sebesar 47,44\%, 1.000.000-3.000.000 sebesar 23,08\%, 3.000.0005.000.000 sebesar 19,23\%, 5.000.000-7.000.000 sebesar 7,69\% dan $>7.000 .000$ sebesar 2,56\%. Tentunya pendapatan ini dapat dipengaruhi oleh berbagai hal seperti jenis pekerjaan dan skala usaha yang sedang dijalankan. Skala usaha, biaya pakan dan tenaga kerja pada usaha peternakan ayam petelur sangat perlu untuk diperhatikan karena berhubungan dengan jumlah produksi serta pendapatan yang akan diperoleh (Mastuti dkk, 2018). Skala usaha dapat berpengaruh terhadap pendapatan, semakin besar skala usaha semakin besar pula pendapatan yang diperoleh dalam usaha peternakan, sehingga pendapatan akan bertambah dan efisiensi usaha dapat ditingkatkan dengan baik.

Uji validitas ini dilakukan untuk memastikan bahwa masing-masing pertanyaan akan terklasifikasi pada variabel yang telah ditentukan. Validitas adalah tingkat keandalan dan kesalahan alat ukur yang digunakan. Instrumen dikatakan valid berarti menunjukkan alat ukur yang dipergunakan untuk mendapatkan data itu valid atau dapat digunakan untuk mengukur apa yang seharusnya diukur (Sugiyono, 2016)

Tabel 3. hasil uji validitas kuesioner Mengenai Kepercayaan Masyarakat Sidenreng Rappang Terhadap kemampuan Magis dari Kulawu Tello

\begin{tabular}{cccc}
\hline No Item & Rsy & R tabel 5\% $(87)$ & Keterangan \\
\hline P 1 & 0.964 & 0.22 & Valid \\
P 2 & 0.960 & 0.22 & Valid \\
\hline
\end{tabular}

Uji Validitas merupakan uji yang menunjukan seberapa besar item-item pernyataan mewakili konsep atau variabel yang diukur. Uji validitas menunjukan ketepatan dan kecermatan suatu alat pengukur dalam melaksanakan fungsi alat ukurnya. Jika $r$ hitung $\geq r$ tabel, maka item item pertanyaan dinyatakan valid. Nilai $r$ hitung dalam uji ini adalah Product Moment Correlation Antara item pertanyaan dengan total skornya.Sedangkan nilai $r$ tabel dapat dilihat pada tabel $\mathrm{r}$ dengan persamaan $\mathrm{N}-2=78-2=76$.

Tabel 4. Hasil uji reliabilitas Mengenai Kepercayaan Masyarakat Sidenreng Rappang Terhadap kemampuan Magis dari Kulawu Tello.

\section{Reliability Statistics}

$\begin{array}{cc}\text { Cronbach's Alpha } & \text { N of Items } \\ .919 & 2\end{array}$


Dimana menurut Ayu dan Sinaulan, (2018). Kuesioner dikatakan reliabel jika nilai cronbach alpha > 0.6 sehingga bisa dikatakan data Mengenai Kepercayaan Masyarakat Sidenreng Rappang Terhadap kemampuan Magis dari Kulawu Tello reliabel atau konsisten.

Tabel 5. Skor dan Persentase (\%) Tingkat Kepercayaan Masyarakat terhadap Kulawu Tello dalam Mengatasi Kerabang Telur yang Lunak.

\begin{tabular}{ccc}
\hline Tingkat Kepercayaan & Total Skor/Y & Persentase (\%) \\
\hline Tinggi & $123 / 234$ & 52,56 \\
Sedang & $50 / 234$ & 21,38 \\
Kurang & $12 / 234$ & 5,13 \\
\hline
\end{tabular}

Berdasarkan data diatas dapat dilihat bahwa tingkat kepercayaan masyarakat terhadap Kulawu Tello dalam mengatasi kerabang telur yang lunak sangat tinggi yaitu 52,56\% adapun persentase tingkat kepercayaan sedang 21,38\% dan yang memiliki tingkat kepercayaan kurang yaitu 5,13\%. Tentunya tingkat kepercayaan tiap individu berbeda-beda tergantung bagaimana mereka meyakini sesuatu sesuai dengan apa yang telah dilakukannya. Pada umumnya masyarakat memiliki kepercayaan yang tinggi terhadap khasiat dari batu Kulawu Tello karena telah menggunakan pada usaha peternakannya. Mereka mengetahui tentang batu tersebut dari sesama peternak dan berbagi informasi bahwa batu Kulawu Tello merupakan batu yang dipercaya dapat mengatasi masalah kerabang telur yang lunak dan juga merupakan metode pengobatan tradisional masyarakat bugis khususnya di Kabupaten Sidenreng Rappang. Dari situlah memunculkan kepercayaan yang tinggi terhadap khasiat dari batu Kulawu Tello. Sikap yang ditunjukkan manusia seperti tingkat kepercayaan terhadap sebuah kebudayaan tercipta dari perjalanan panjang yang dilalui dan dipengaruhi oleh beberapa faktor seperti lingkungan dan keluarga (Nur, 2020).

Kepercayaan merupakan kondisi mental yang didasarkan oleh situasi seseorang dan konteks sosialnya (Sugara dan Dewantara, 2017). Misalnya saja peternak ayam ras petelur yang telah menggunakan batu Kulawu Tello dalam mengatasi kerabang telur yang lunak memiliki tingkat kepercayaan yang lebih tinggi karena telah merasakan manfaat dari batu tersebut. Kepercayaan awal masyarakat di Kabupaten Sidenreng Rappang tidak berbeda dengan perkembangan awal masyarakat pada umumnya yang dipengaruhi oleh kepercayaan religius magis. Pada saat itu kepercayaan masyarakat akan kekuatan dari kosmologi sangat kuat sehingga secara tidak langsung sosio-kultural yang di bangunnya dalam kehidupannya sehari-hari berdasarkan kepercayaannya pada kekuatan magis. Pada umumnya masyarakat mengenal kepercayaan animisme, dinamisme dan totemisme. Kepercayaan masyarakat tersebut dapat berupa kepercayaan terhadap benda-benda yang memiliki kekuatan gaib (dinamisme), seperti, ketobok, makam, kemalik, keris, tombak dan lain sebagainya (Afandi, 2016). 


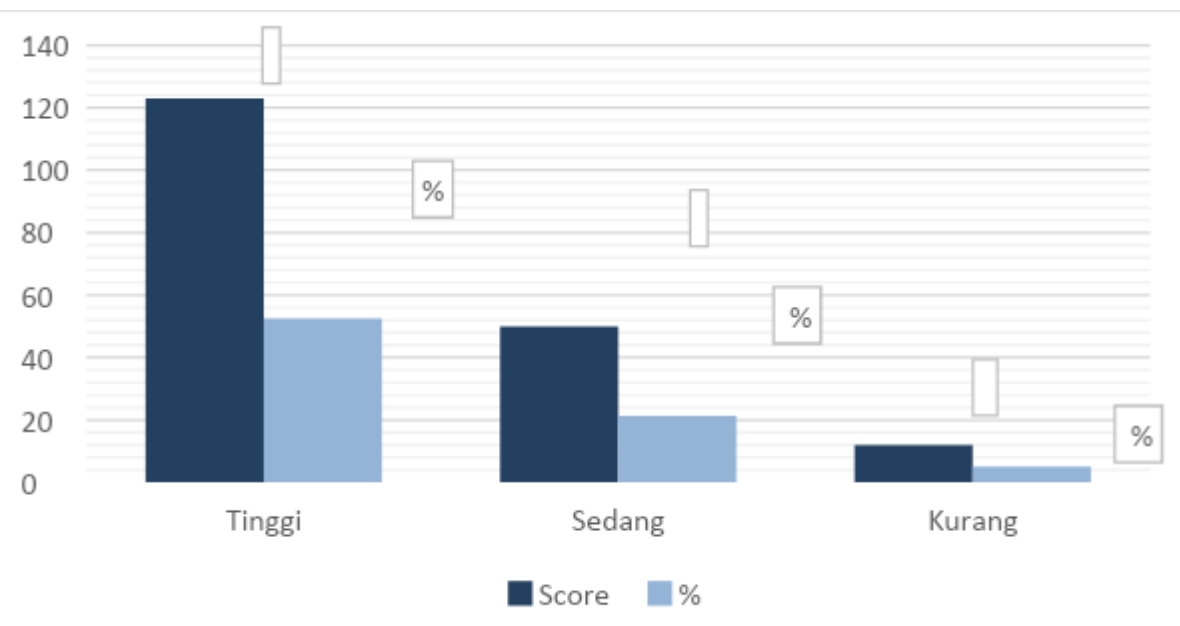

Gambar 2. Grafik perbandingan Tingkat Kepercayaan Masyarakat terhadap Kulawu Tello dalam Mengatasi Kerabang Telur yang Lunak.

Selain itu masyarakat Desa Manisa Kecamatan Baranti dan Desa Mario mempercayai Kulawu Tello mampu diberikan kepada ayam petelur untuk meningkatkan performa produksi ayam petelur.

Tabel 6. Skor dan Persentase (\%) Tingkat Kepercayaan Masyarakat terhadap Kulawu Tello dalam Meningkatan Performa Ayam Petelur.
Tingkat Kepercayaan
Frekuensi
Persentase (\%)

\begin{tabular}{ccc}
\hline Tinggi & $111 / 234$ & 47,44 \\
Sedang & $62 / 234$ & 26,49 \\
Kurang & $10 / 234$ & 4,27 \\
\hline
\end{tabular}

Berdasarkan data diatas dapat dilihat bahwa tingkat kepercayaan masyarakat terhadap Kulawu Tello dalam meningkatkan performa ayam petelur sebesar 47,44\% adapun persentase tingkat kepercayaan sedang 26,49\% dan yang memiliki tingkat kepercayaan kurang yaitu 4,27\%. Kepercayaan ini muncul karena pada zaman dahulu peternak belum mengenal adanya pengobatan medis pada dunia peternakan khususnya ayam petelur. Disamping itu adanya batu Kulawu Tello yang dipercaya dapat mengatasi masalah kerabang telur yang lunak dan meningkatkan performa ayam petelur menyebabkan masyarakat menggunakan batu ini sebagai solusi tradisional dalam mengatasi kerabang telur yang lunak. Jika peternak melihat performa ternaknya mengalami penurunan, maka mereka akan menggunakan batu ini dengan merendamnya selama \pm 12 jam di dalam air, kemudian diberikan pada ternak mereka.

Kepercayaan adalah suatu hal yang memang benar-benar kita yakini akan kebenaran dari benda tersebut contoh mitos dari batu Kulawu Tello bahwa masyarakat betul-betul percaya akan mitos tersebut sehingga apa yang kita yakini itu betul-betul nampak kebenaran dari benda tersebut (Firsal, 2015). Dalam penggunaan batu tersebut yang dipercaya dapat mengatasi kerabang telur yang lunak tentunya tidak bertolak belakang dari ajaran agama yang pada 
umumnya dianut di Indonesia adalah Agama Islam. Dalam kajian Islam, budaya suku Bugis meyakini bahwa Islam sebagai agama Rahmatan Lil alamin tidak berbenturan dengan budaya suku Bugis (Nur, 2020). Pemakaian batu ini diawali dengan niat dan berharap kesembuhan untuk ternak yang mengalami kerabang telur yang lunak, setelah itu memberikan air tersebut pada ayam. Dalam bekerja niat seorang muslim merupakan hal yang sangat penting, termasuk semua aktivitas yang dilakukannya. Dasar kerja atau amal adalah niat yang akan membedakan suatu tindakan itu berupa kebajikan atau tidak. (Walian, 2013). Tentunya sesuatu yang dimulai dengan niat yang baik akan menghasilkan yang baik pula, dimana setelah pemakaian 3-5 hari ayam yang menderita kerabang telur lunak atau produksi yang menurun dapat berproduksi kembali seperti semula.

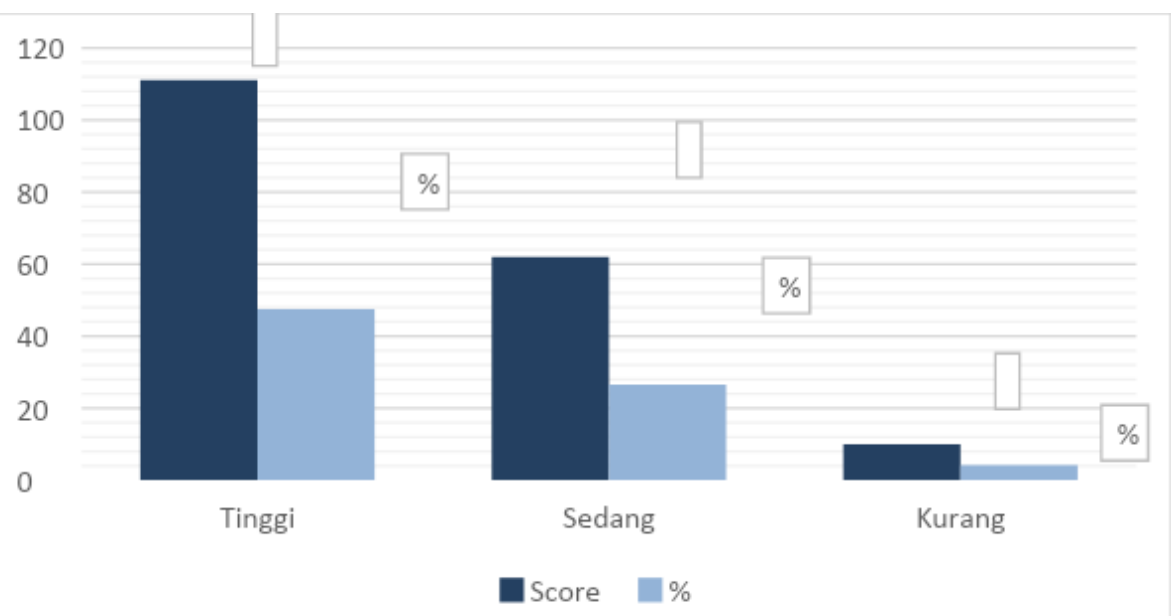

Gambar 3. Grafik perbandingan Tingkat Kepercayaan Masyarakat terhadap Kulawu Tello dalam Meningkatan Performa Ayam Petelur.

\section{KESIMPULAN}

Berdasarkan penelitian yang telah dilakukan untuk mengetahui tingkat kepercayaan Masyarakat Sidenreng Rappang terhadap kemampuan magis Kulawu Tello dalam meningkatan performa ayam petelur yang dilakukan di kelurahan manisa kecamatan baranti dapat disimpulkan bahwa tingkat kepercayaan masyarakat terhadap Kulawu Tello dalam mengatasi kerabang telur yang lunak sangat tinggi yaitu 52,56\% adapun persentase tingkat kepercayaan sedang 21,38\% dan yang memiliki tingkat kepercayaan kurang yaitu 5,13\%. Dan untuk tingkat kepercayaan masyarakat terhadap Kulawu Tello dalam meningkatkan performa ayam petelur sebesar 47,44\% adapun persentase tingkat kepercayaan sedang 26,49\% dan yang memiliki tingkat kepercayaan kurang yaitu 4,27\%.

\section{DAFTAR PUSTAKA}

Afandi, A. 2018. Kepercayaan Animisme-Dinamisme Serta Adaptasi Kebudayaan Hindu-Budha Dengan Kebudayaan Asli Di Pulau Lombok-NTB. Historis: Jurnal Kajian, Penelitian dan Pengembangan Pendidikan Sejarah, 1(1): 1-9.

Amin, M. Al, and Juniati, D. 2017. Klasifikasi kelompok umur manusia berdasarkan analisis dimensi fraktal box counting dari citra wajah dengan deteksi tepi canny. Mathunesa: 
Jurnal Ilmiah Matematika, 2(6): 33-42.

Ayu, D. K., and Sinaulan, J. H. 2018. Pengaruh Insentif dan Disiplin Kerja terhadap Kinerja Karyawan pada PT Bintang Satoe Doea. Jurnal Ekonomi, 20(3),:373-383.

Corneles, S., and Losu, F. 2015. Hubungan Tingkat Pendidikan Dengan Pengetahuan Ibu Hamil Tentang Kehamilan Risiko Tinggi. (JIDAN) Jurnal Ilmiah Bidan, 3(2): 51-55.

Dewi, R. S., Ilahi, S. F. N., Aryani, F., Pratiwi, E., and Agustini, T. T. 2019. Persepsi Masyarakat Mengenai Obat Tradisional di Kelurahan Simpang Baru Kecamatan Tampan Kota Pekanbaru. Jurnal Penelitian Farmasi Indonesia, 8(2): 75-79.

Dewi, S. K., and Sudaryanto, A. 2020. Validitas dan reliabilitas kuesioner pengetahuan , sikap dan perilaku. Program Studi Keperawatan, Universitas Muhammadiyah Surakarta, 7379.

Dharmawati, I. G. A. A., and Wirata, I. N. 2016. Hubungan tingkat pendidikan, umur, dan masa kerja dengan tingkat pengetahuan kesehatan gigi dan Mulut Pada Guru Penjaskes Sd Di Kecamatan Tampak Siring Gianyar. Jurnal Kesehatan Gigi, 4(1): 1-5.

Firsal. 2015. Kepercayaan Masyarakat Terhadap Mitos Batu Mustika (study kasus masyarakat parenrring soppeng). Skripsi. Fakultas Keguruan dan Ilmu Pendidikan Universitas Muhammadiyah Makassar, Makassar.

Husain, B. A. 2018. Pengaruh Pengalaman Kerja Terhadap Kinerja Karyawan (PT Bank Negara Indonesia TBK Kantor Cabang Bumi Serpong Damai). Jurnal Disrupsi Bisnis: Jurnal Ilmiah Prodi Manajemen, Fakultas Ekonomi, Universitas Pamulang, 1(2): 1-20.

Mastuti, R., Supristiwendi, and Andika. 2018. Pengaruh Skala Usaha, Biaya Pakan Dan Penggunaan Tenaga Kerja Terhadap Pendapatan Peternak Ayam Broiler Pedaging (Gallus Sp) Di Kecamatan Idi Rayeuk Kabupaten Aceh Timur. Jurnal Penelitian Agrisamudra, 5(1): 75-83.

Nur, A. 2020. Mistisisme tradisi mappadendang di Desa Allamungeng Patue, Kabupaten Bone. Jurnal Khitah: Kajian Islam, Budaya dan Humaniora, 1(1): 1-16.

Rohani, ST., Rasyid, I., Siregar, A. R., Aminawar, M., Darwis, M., and Kurniawan, M. E. 2019. Alasan peternak ayam ras petelur memilih pakan produksi lokal di Kabupaten Sidrap Provinsi Sulawesi Selatan. Agrokompleks, 19(1): 23-26.

Sugara, A., and Dewantara, R. Y. 2017. Analisis Kepercayaan Dan Kepuasan Terhadap Penggunaan Sistem Transaksi Jual Beli Online (Studi Pada Konsumen “Z”). Jurnal Administrasi Bisnis, 52(1): 8-15.

Suhardin. 2016. Pengaruh Perbedaan Jenis Kelamin Dan Pengetahuan Tentang Konsep Dasar Ekologi Terhadap Kepedulian Lingkungan. EDUKASI: Jurnal Penelitian Pendidikan Agama dan Keagamaan, 14(1): 117-132.

Walian, A. W. 2012. Konsepsi Islam Tentang Kerja Rekonstruksi Terhadap Pemahaman Kerja Seorang Muslim. An Nisa'a, 1(1): 65-80. 